\title{
Detection of Persistent Human Parvovirus 4 Infection in Patients with Antiphospholipid Syndrome
}

\author{
Mao-Yuan Chen ${ }^{*}$, Chien-Ching Hung and Kuang-Lun Lee \\ Department of Internal Medicine, National Taiwan University Hospital, Taipei, Taiwan
}

"Corresponding author: Chen MY, Department of Internal Medicine, National Taiwan University Hospital, No. 7, Chung Shan South Road, Taipei, Taiwan, Tel: 886-2-23123456; E-mail: maoyuanchen@ntu.edu.tw

Received date: May 22, 2017; Accepted date: June 13, 2017; Published date: June 16, 2017

Copyright: (c) 2017 Chen MY et al. This is an open-access article distributed under the terms of the Creative Commons Attribution License, which permits unrestricted use, distribution, and reproduction in any medium, provided the original author and source are credited.

\begin{abstract}
Parvovirus 4 (PARV4) is one of the emerging human parvoviruses discovered recently. PARV4 has long-lasting persistence in tissues after primary infection, but persistent PARV4 viremia has yet to be effectively detected in humans. In the present work, longitudinal serum samples from eleven patients with antiphospholipid syndrome were tested by nested polymerase chain reaction for the presence of PARV4 DNA. In one patient, PARV4 4 DNA was detected in all longitudinal serum samples collected over a period of 119 months. In addition, PARV4 DNA was present in two or more longitudinal serum samples from seven other patients. Two possible explanations are a persistent infection with intermittent low viral load below detection limit and a recurrent reactivation of latent infection. In conclusion, to our knowledge, this is the first direct evidence of detection of persistent PARV4 infection. Placental transmission may be one of the major routes of PARV4 infection in endemic areas if women of child-bearing age have continuous or intermittent circulating PARV4 DNA seen in our patients.
\end{abstract}

Keywords: Parvovirus 4; Persistent infection; Antiphospholipid syndrome

\section{Introduction}

The discovery of human parvovirus 4 (PARV4) in an intravenous drug user who had acute viral infection syndrome was reported in 2005 [1]. PARV4 is a single-stranded DNA virus that belongs to the subfamily Parvovirinae in the family Parvoviridae and is now grouped in the genus Tetraparvovirus [2]. Three PARV4 genotypes have been identified, genotype 1 and 2 are predominant in Europe, North America, and Asia; genotype 3 is endemic in Africa [3]. In Taiwan, all the PARV4 isolates detected to date are genotype 2 . The clinical diseases associated with PARV4 infection are not clear at present.

Geographical differences in the seroprevalence of PARV4 have been demonstrated. In one study, none of the blood samples from 161 British orthopedic outpatient attendees and 199 French blood donors contained anti-PARV4 antibodies. Whereas the seropositive rates among persons not infected by the blood-borne viral infections hepatitis $\mathrm{C}$ virus (HCV) and HIV were $37 \%$ and $35 \%$ in Burkina Faso and Democratic Republic of the Congo, respectively [4]. Parenteral transmission is the major route of PARV4 infection in the United Kingdom [5], but there is a low likelihood of parenteral transmission in the two Central African countries; the routes responsible for widespread exposure to PARV4 infection in those two countries are not known. Of note, studies conducted in Germany and Italy on PARV4 persistence in tissues of non-intravenous drug users and nonHIV infected individuals have detected PARV4 DNA in 15\% (13/87) of liver tissues and in $49 \%(17 / 35)$ of myocardium tissues, respectively $[6,7]$. These data suggest that PARV4 infection is not rare in these two countries, but how these persons acquired PARV4 infection is not known. Because serological tests for anti-PARV4 antibodies were not performed in the two latter studies, it was not possible to compare such findings with the very low PARV4 seroprevalence rates detected elsewhere in Europe [1,8,9].

The low-levels of PARV4 DNA in tissues [6] may reflect a latent infection or a persistent infection where low replication rates occur. It has been shown that the T cell response to the PARV4 nonstructural (NS) protein is strong and sustained in patients with HCV infection [10]. Thus, the continuous stimulation of CD8+ T cells is consistent with the hypothesis that a low-level persistent viral replication occurs in tissues. The viral progeny may then spill into circulation. PARV4 DNA has been detected in follow-up blood samples from seropositive individuals in our previous study [11], but whether they had a persistent PARV4 infection or a reactivation of latent infection could not be determined. To differentiate the two possibilities, a study of longitudinal serum samples is required.

One PARV4-infected mother who gave birth to a newborn with hydrops in our previous report [12] was tested positive for a antiphospholipid antibody (aPL)anti-beta2-glycoprotein I IgGby chance. Because the production of aPLs may be related to certain infections (including viral infections) in susceptible individuals [13] and longitudinal serum samples were available from patients with antiphospholipid syndrome (APS), these samples were tested in the present study to detect the existence of persistent PARV4 infection.

\section{Materials and Methods}

\section{Serum samples}

According to the revised classification criteria for APS, the diagnosis requires a clinical event of arterial or venous thrombosis or pregnancy morbidity and the presence of at least one of the three aPLs, namely anti-cardiolipin antibodies IgG or IgM, anti-beta2-glycoprotein I IgG or IgM, or lupus anticoagulant, on two or more occasions at least 12 weeks apart [14]. The clinical event and the presence of aPL in 11 
Citation: Chen MY, Hung CC, Lee KL (2017) Detection of Persistent Human Parvovirus 4 Infection in Patients with Antiphospholipid Syndrome.

Page 2 of 4

patients are listed in Table 1 . The interval between the first and last serum sample was 16-119 months, with a mean of 59.5 months. Informed consent was obtained from these patients.

\begin{tabular}{|c|c|c|c|c|c|}
\hline $\begin{array}{l}\text { Patient } \\
\text { (sex) }\end{array}$ & $\mathrm{aPL}$ & $\begin{array}{l}\text { Clinical } \\
\text { event }\end{array}$ & $\begin{array}{l}\text { Total } \\
\text { serum } \\
\text { samples }\end{array}$ & $\begin{array}{l}\text { Date of the } \\
\text { 1st and last } \\
\text { sample }\end{array}$ & $\begin{array}{l}\text { Anti-PARV4 } \\
\text { IgG }\end{array}$ \\
\hline \multirow[t]{2}{*}{$A(F)$} & \multirow[t]{2}{*}{$\mathrm{aCL} \lg G$} & \multirow[t]{2}{*}{ SA } & \multirow[t]{2}{*}{8} & $\begin{array}{l}\text { 02-12 } \\
\text { (YY/MM) }\end{array}$ & \multirow{2}{*}{$\begin{array}{l}\text { weakly } \\
\text { positive }\end{array}$} \\
\hline & & & & $12-11$ & \\
\hline \multirow{2}{*}{$B(F)$} & \multirow{2}{*}{$\mathrm{aCL} \lg G$} & \multirow{2}{*}{ SA } & \multirow{2}{*}{8} & 05-08 & \multirow{2}{*}{ positive } \\
\hline & & & & $11-08$ & \\
\hline \multirow{2}{*}{$C(F)$} & \multirow{2}{*}{$\mathrm{aCL} \lg G$} & \multirow{2}{*}{ SA } & \multirow{2}{*}{8} & $06-07$ & \multirow{2}{*}{$\begin{array}{l}\text { weakly } \\
\text { positive }\end{array}$} \\
\hline & & & & $11-11$ & \\
\hline \multirow{2}{*}{$\mathrm{D}(\mathrm{F})$} & \multirow{2}{*}{$\begin{array}{l}\mathrm{aCL} \lg \mathrm{G}, \\
\text { B2-GP I }\end{array}$} & \multirow{2}{*}{ SA } & \multirow{2}{*}{7} & 09-07 & \multirow{2}{*}{$\begin{array}{l}\text { weakly } \\
\text { positive }\end{array}$} \\
\hline & & & & 04-13 & \\
\hline \multirow{2}{*}{$E(F)$} & \multirow{2}{*}{$\begin{array}{l}\mathrm{aCL} \operatorname{lgG}, \\
\text { B2-GP I }\end{array}$} & \multirow{2}{*}{$\mathrm{Ml}$} & \multirow{2}{*}{7} & 06-11 & \multirow{2}{*}{$\begin{array}{l}\text { weakly } \\
\text { positive }\end{array}$} \\
\hline & & & & $11-06$ & \\
\hline \multirow{2}{*}{$F(M)$} & \multirow{2}{*}{$\begin{array}{l}\text { aCL } \quad \text { IgG, } \\
\text { B2-GP I, } \\
\text { LA }\end{array}$} & \multirow{2}{*}{ PE, DVT } & \multirow{2}{*}{5} & 04-04 & \multirow{2}{*}{$\begin{array}{l}\text { weakly } \\
\text { positive }\end{array}$} \\
\hline & & & & $11-10$ & \\
\hline \multirow{2}{*}{$G(M)$} & \multirow{2}{*}{$\mathrm{aCL} \lg G$} & \multirow{2}{*}{ CAD } & \multirow{2}{*}{5} & 02-05 & \multirow{2}{*}{ negative } \\
\hline & & & & 08-05 & \\
\hline & & & & $10-07$ & weakly \\
\hline 等 & ave ige & r & To & $11-11$ & positive \\
\hline & $\mathrm{aCL} \quad \mathrm{IgG}$, & & & $11-02$ & \\
\hline (1) & LA & r & $T$ & 14-04 & tivgerio \\
\hline & ß2-GP & Ctroke & & 06-01 & monitivg \\
\hline$J(r)$ & LA & Stroke & 4 & $09-08$ & positive \\
\hline$K(F)$ & $\mathrm{aCL} \quad \lg \mathrm{G}$, & SA & 4 & 08-06 & negative \\
\hline$n(r)$ & B2-GP I & $O A$ & 4 & $11-09$ & Thative \\
\hline
\end{tabular}

Sex: female (F); male (M); aCL: anti-cardiolipin; ß2-GP I: anti-beta2-glycoprotein I; LA: Lupus Anticoagulant; SA: recurrent spontaneous abortion; MI: acute Myocardial Infarction; PE: Pulmonary Embolism; DVT: Deep Vein Thrombosis; CAD: Coronary Artery Disease; stroke: ischemic stroke.

Table 1: Data of patients with antiphospholipid syndrome.

\section{Nested polymerase chain reaction $(\mathrm{PCR})$}

Using a High Pure Viral Nucleic Acid Kit (Roche, Mannheim Germany), viral DNA was extracted from $200 \mu \mathrm{L}$ of serum sample following the manufacturer's instructions. The amount of elution buffer was $50 \mu \mathrm{L}$ for each sample, and $5 \mu \mathrm{L}$ was used in each reaction.

The primers for detecting PARV4 (designed to detect genotype 2) were as follows: forward: 5'-ATTTCTGTAGCTCCACCAGGAGC-3' (nucleotides 316-338 in ORF-2); reverse: $5^{\prime}$ GGTAGGACCTGAGAAAGTTGAACATC-3' (nucleotides 959-934); inner forward: 5'-ACCTACCGTTGAAAACATTG-3' (nucleotides
441-460);

and

inner

reverse:

$5^{\prime}-$

CCATAAACCTCTAATAGCATTGCC-3' (nucleotides 903-880). Taq DNA Polymerase 2x Master Mix Red (Amplicon, Denmark) was used to amplify PARV4 DNA according to the manufacturer's instructions. The nested PAR4 PCR program was as such for the first and second rounds: $94^{\circ} \mathrm{C}$ for $2 \mathrm{~min}$, followed by 36 cycles of $94^{\circ} \mathrm{C}$ for $30 \mathrm{~s}, 52^{\circ} \mathrm{C}$ for $30 \mathrm{~s}, 72^{\circ} \mathrm{C}$ for $30 \mathrm{~s}$ and a final extension at $72^{\circ} \mathrm{C}$ for $7 \mathrm{~min}$. The PCR products were then sequenced. We have tested our PCR method on DNA samples with a concentration of 500, 250, 125 and 62.5 PARV4 genome (plasmid) copies $/ \mathrm{mL}$ and found the number of positive tests from six replicates was $6,5,2$ and 1, respectively. Because a low viral load $(<2 \log 10$ genome copies $/ \mathrm{mL}$ ) which could not be quantified by real-time PCR has been reported in PARV4 DNA-positive blood donors [15], six separate PCR replicates were performed in the present study. A negative control was included in every replicate. Anti-PARV4 IgG was determined by an immunoblot assay developed [16].

\section{Results}

PARV4 DNA was detected in all eight longitudinal serum samples collected over a period of 119 months from patient A (Table 2).

\begin{tabular}{|c|c|c|c|c|c|c|}
\hline \multirow{2}{*}{$\begin{array}{l}\text { Date } \\
\text { (YY/MM) }\end{array}$} & \multirow{2}{*}{$\begin{array}{l}\text { Positiv } \\
\text { e } \\
\text { replicat } \\
\text { e } \\
2\end{array}$} & \multirow{2}{*}{$\begin{array}{l}\text { Sequenc } \\
\text { e }\end{array}$} & \multicolumn{4}{|c|}{$\begin{array}{l}\text { The position and nucleotide substitution } \\
\text { in ORF-2 }\end{array}$} \\
\hline & & & 715 TC & & & \\
\hline \multirow{2}{*}{$08-03$} & 2 & A2-1 & 715 TC & & & \\
\hline & & A2-2 & 501 AG & 715 TC & & \\
\hline 08-06 & 1 & A3 & $501 \mathrm{AG}$ & 575 TC & 715 TC & $738 \mathrm{TC}$ \\
\hline 09-07 & 2 & A4 & 715 TC & & & \\
\hline $09-10$ & 2 & A5 & 501 AG & 715 TC & & \\
\hline \multirow{2}{*}{$10-01$} & 5 & A6-1 (3)\# & 715 TC & & & \\
\hline & & A6-2 (2) & $551 \mathrm{~A}$ & 715 TC & & \\
\hline $11-09$ & 1 & A7 & 715 TC & & & \\
\hline \multirow[t]{2}{*}{$12-11$} & 3 & A8-1 (2) & 715 TC & & & \\
\hline & & A8-2 (1) & 501 AG & 504 TC & 541 AG & 715 TC \\
\hline
\end{tabular}

Table 2: The nucleotide sequences of PCR products obtained from the patient who had detectable PARV4 DNA in all eight longitudinal samples (as compared to the master sequence GenBank GU120197.1).

\begin{tabular}{|l|l|l|l|l|l|l|}
\hline $\begin{array}{l}\text { Patient } \\
\text { Date }\end{array}$ & $\begin{array}{l}\text { Positive } \\
\text { replicat } \\
\text { e }\end{array}$ & $\begin{array}{l}\text { Sequenc } \\
\text { e }\end{array}$ & \multicolumn{4}{|l|}{$\begin{array}{l}\text { The position and nucleotide substitution in } \\
\text { ORF-2 }\end{array}$} \\
\hline \multirow{2}{*}{ B 05-08 } & 2 & B1-1 & 715 TC & & & \\
\cline { 2 - 7 } & & B1-2 & 509 AG/A & 715 TC & & \\
\hline B 06-11 & 1 & B3* & 715 TC & & & \\
\hline B 07-01 & 2 & B4-1 & 632 GC & 715 TC & & \\
\hline
\end{tabular}


Page 3 of 4

\begin{tabular}{|l|l|l|l|l|l|l|}
\hline & & B4-2 & 700 GA & 715 TC & 730 GA & \\
\hline \multirow{2}{*}{ B 11-08 } & 3 & B8-1 (2)\# & 715 TC & & & \\
\cline { 2 - 7 } & & B8-2 (1) & 509 AG & 715 TC & & \\
\hline C 06-07 & 1 & C1 & 715 TC & & & \\
\hline C 09-08 & 1 & C4 & 715 TC & & & \\
\hline C 10-08 & 2 & C5 & 715 TC & & & \\
\hline C 11-06 & 2 & C7-1 & 576 TG & 715 TC & & \\
\hline & & C7-2 & 695 AG & 715 TC & & \\
\hline D 09-07 & 1 & D1 & 500 AG & & & \\
\hline D 11-06 & 1 & D3 & 715 TC & & & \\
\hline D 11-10 & 1 & D5 & 715 TC & & & \\
\hline D 13-04 & 1 & D7 & 715 TC & 726 GA & & \\
\hline E 06-11 & 1 & E1 & 504 TC & 715 TC & & \\
\hline E 09-12 & 1 & E2 & 547 TC & 572 AG & 715 TC & 825 GA \\
\hline E 10-08 & 1 & E4 & 504 TC & 715 TC & & \\
\hline E 11-03 & 1 & E6 & 715 TC & & & \\
\hline Date (YY/MM); *: the serial numbers of serum samples; \#: the total number of \\
PCR products with the specific nucleotide sequence. & & \\
\hline
\end{tabular}

Note that none of the 34 DNA-positive serum samples yielded consistent positive results in all six replicates and 23 of them had only one positive replicate. The positive results are unlikely to have been caused by contamination because no positive results were obtained for negative controls. The nucleotide substitutions in PCR products as compared with the sequence GenBank GU120197.1 [16] are listed in Tables 2-4. Twenty-four PCR products had nucleotide sequence identical to $\mathrm{A} 1$ and 26 products had nucleotide sequences different from A1. Anti-PARV4 IgG was detected in eight patients (Table 1), seven of them had multiple DNA-positive longitudinal serum samples.

Several circulating PARV4 viral strains were observed in the same patient (patients $\mathrm{A}-\mathrm{H}$ ). When two or more PCR products were obtained from the same DNA aliquot, their nucleotide sequences could be different (serum sample numbers A2, A6, A8, B1, B4, B8 and C7 in Tables 2 and 3). In addition, the PARV4 strains detected in serum samples from the same patient at different time points also may have had variations in nucleotide sequences (patients A-H). Finally, for two nucleotide sequences (samples B1 and G5), dual signals were noted at the same nucleotide position, which suggested the detection of two circulating viral strains.

The existence of a persisting viral strain is supported by signature substitutions in some, but not all, of the viral sequences in the longitudinal serum samples collected at different time points; for example, 501 in patient A, 509 in patient B and 504 in patient $\mathrm{E}$. The nucleotide substitution at position 517 (sample K3) resulted in a stop codon (CAA to TAA). Thus, another replication-competent viral strain must exist in patient $\mathrm{K}$ to help the proliferation of the defective virus.

Table 3: The nucleotide sequences of PCR products obtained from four patients who had detectable PARV4 DNA in four longitudinal serum samples (as compared to the master sequence GenBank GU120197.1).

Moreover, PARV4 DNA was detected in two or more longitudinal serum samples from seven other patients (Tables 3 and 4) and in one of the longitudinal serum samples from three patients (Table 4).

\begin{tabular}{|l|l|l|l|l|l|l|}
\hline $\begin{array}{l}\text { Patient } \\
\text { Date }\end{array}$ & $\begin{array}{l}\text { Positive } \\
\text { replicate }\end{array}$ & $\begin{array}{l}\text { Sequenc } \\
\text { e }\end{array}$ & \multicolumn{4}{|l|}{ Position and nucleotide substitution in } \\
ORF-2 & \multicolumn{1}{l|}{} \\
\hline F 10-07 & 1 & F2 & 715 TC & 869 AG & & \\
\hline F 11-06 & 1 & F4 & 702 TC & 715 TC & & \\
\hline G 07-03 & 1 & G3 & 715 TC & & & \\
\hline G 08-01 & 1 & G4 & 518 AG & 519 AG & 674 TC & 715 TC \\
\hline G 08-05 & 1 & G5 & 607 TC/T & 715 TC & & \\
\hline H 11-03 & 1 & H5 & & & & \\
\hline H 11-11 & 1 & H10 & 690 TA & 715 TC & 795 CT & \\
\hline I 11-02 & 1 & I1 & 715 TC & & & \\
\hline J 07-06 & 1 & J2 & 715 TC & 784 TC & & \\
\hline K 10-09 & 1 & K3 & 517 CT & 702 TC & 715 TC & 766 AG \\
\hline Date (YY/MM); * the serial numbers of serum samples. & & \\
\hline
\end{tabular}

Table 4: The nucleotide sequences of PCR products obtained from six patients who had detectable PARV4 DNA in 1-3 longitudinal serum samples (as compared to the master sequence GenBank GU120197.1).

\section{Discussion}

Not all 11 PARV4 DNA-positive patients had anti-PARV4 IgG, although one of the three IgG-negative patients was weakly positive in the anti-PARV4 IgM immunoblot (patient I). The absence of antiPARV4 antibodies in DNA-positive patients may be due to sensitivity limitations of the detection method or the loss of antibodies over time. A similar finding has been reported in HCV-infected patients who had a T cell response to PARV4 NS protein but were seronegative [10].

The absence of PARV4 DNA in the blood samples from 29 seropositive British blood donors and 58 seropositive South African study subjects $[17,18]$ is consistent with the belief that infections with PARV4 are not followed by long-term viremia $[4,19]$. The $0 \%$ PARV4 DNA-positive rates among 670 French blood donors [20,21] are also in agreement with the observation of short-lived viremia after primary infection [19]. However, PARV4 DNA could be detected in $1 \%, 2 \%$, $4 \%, 17 \%$ and $24 \%$ of blood donors from Italy, Los Angeles (USA), Thailand, Iran and France, respectively [15,22-25]. Regarding these DNA-positive blood donors, it is not known whether they had recent or remote infections. In our present study, we found the direct evidence of persistent PARV4 infection lasting for 119 months in a single APS patient, which supports the hypothesis that long-term viremia can occur. In addition, the intermittent ability to detect PARV4 DNA in seven patients may represent persistent PARV4 infections with a viral load too low to be detected at some time points, although recurrent reactivation of latent infections is also a possible explanation. Low-level viremia is reflected by the inconsistent positivity in PCR replicates and the fact that two-thirds of DNA-positive blood samples had only one positive result from six replicates.

The transmission of PARV4 infection in endemic areas requires a viral reservoir and routes which can spread the virus effectively. In our 
recent study, PARV4 DNA could be detected in $18 \%$ of 39 women of child-bearing age using the method described here (Chen MY, unpublished data). The frequent detection of circulating PARV4 DNA and the discovery of long-term viremia in the present study increase the likelihood of placental transmission in endemic areas.

The detection of PARV4 DNA in all eleven APS patients is unexpected. However, our study was limited by the small patient number and the presence of PARV4 DNA in our patients with APS may be simply coincidental because PARV4 DNA can be detected in healthy individuals [11]. Thus, the clinical significance of being able to frequently detect PARV4 DNA in APS patients is not known and warrants further investigation.

\section{References}

1. Jones MS, Kapoor A, Lukashov VV, Simmonds P, Hecht F, et al. (2005) New DNA viruses identified in patients with acute viral infection syndrome. J Virol 79: 8230-8236.

2. Cotmore SF, Agbandje-McKenna M, Chiorini JA, Mukha DV, Pintel DJ, et al. (2014) The family Parvoviridae. Arch Virol 159: 1239-1247.

3. Matthews PC, Malik A, Simmons R, Sharp C, Simmonds P, et al. (2014) PARV4: an emerging tetraparvovirus. PLoS Pathog 10: e1004036.

4. Sharp CP, Vermeulen M, Nébié Y, Djoko CF, LeBreton M, et al. (2010) Epidemiology of human parvovirus 4 infection in Sub-Saharan Africa. Emerg Infect Dis 16: 1605-1607.

5. Sharp CP, Lail A, Donfield S, Simmons R, Leen C, et al. (2009) High frequencies of exposure to the novel human parvovirus PARV4 in hemophiliacs and injection drug users, as detected by a serological assay for PARV4 antibodies. J Infect Dis 200: 1119-1125.

6. Schneider B, Fryer JF, Reber U, Fischer HP, Tolba RH, et al. (2008) Persistence of novel human parvovirus PARV4 in liver tissue of adults. J Med Virol 80: 345-351.

7. Corcioli F, Zakrzewska K, Fanci R, De Giogi V, Innocenti M, et al. (2010) Human parvovirus PARV4 DNA in tissues from adult individuals: a comparison with human parvovirus B19 (B19V). Virol J 7: 272-276.

8. Lahtinen A, Kivelä P, Hedman L, Kumar A, Kantele A, et al. (2011) Serodiagnosis of primary infections with human parvovirus 4, Finland. Emerg Infect Dis 17: 79-82.

9. Von Linstow ML, Rosenfeldt V, Lindberg E, Jensen L, Hedman L, et al. (2015) Absence of novel human parvovirus (PARV4) in Danish mothers and children. J Clin Virol 65: 23-25.

10. Simmons R, Sharp C, Sims S, Kloverpris H, Goulder P, et al. (2011) High frequency, sustained $\mathrm{T}$ cell responses to PARV4 suggest viral persistence in vivo. J Infect Dis 203: 1378-1387.

11. Chen MY, Hung CC, Lee KL (2015) Detection of human parvovirus 4 viremia in the follow-up blood samples from seropositive individuals suggests the existence of persistent viral replication or reactivation of latent viral infection. Virol J 12: 94.

12. Chen MY, Yang SJ, Hung CC (2011) Placental transmission of human parvovirus 4 in newborns with hydrops, Taiwan. Emerg Infect Dis 17: 1954-1956.

13. Shoenfeld Y, Blank M, Cervera R, Font J, Raschi E, et al. (2006) Infectious origin of the antiphospholipid syndrome. Ann Rheum Dis 65: 2-6.

14. Miyakis S, Lockshin MD, Atsumi T, Branch DW, Brey RL, et al. (2006) International consensus statement on an update of the classification criteria for definite antiphospholipid syndrome (APS). J Thromb Haemost 4: 295-306.

15. Fryer JF, Delwart E, Hecht FM, Bernardin F, Jones MS, et al. (2007) Frequent detection of the parvoviruses, PAR4 and PARV5, in plasma from blood donors and symptomatic individuals. Transfusion 47: 1054-1061.

16. Yang SJ, Hung CC, Chang SY, Lee KL, Chen MY (2011) Immunoglobulin $\mathrm{G}$ and $\mathrm{M}$ antibodies to human parvovirus 4 (PARV4) are frequently detected in patients with HIV-1 Infection. J Clin Virol 51: 64-67.

17. Maple PA, Beard S, Parry RP, Brown KE (2013) Testing UK blood donors for exposure to human parvovirus 4 using a time-resolved fluorescence immunoassay to screen sera and western blot to confirm reactive samples. Transfusion 53: 2575-2584.

18. Matthews PC, Sharp CP, Malik A, Gregory WF, Adland E, et al. (2015) Human Parvovirus 4 infection among mothers and children in South Africa. Emerg Infect Dis 21: 713-715.

19. Simmons R, Sharp C, Levine J, Bowness P, Simmonds P, et al. (2013) Evolution of CD8+ T cell responses after acute PARV4 infection. J Virol 87: 3087-3096.

20. Biagini P, Dussol B, Touinssi M, Brunet P, Picard C, et al. (2008) Human parvovirus 4 in kidney transplant patients, France. Emerg Infect Dis 14: 1811-1812.

21. Servant-Delmas A, Laperche S, Mercier M, Elghouzzi MH, Lionnet F, et al. (2009) Human parvovirus 4 in recipients of cellular product and in blood donors: epidemiologic similarity with B19 parvovirus. Transfusion 49: 1771-1773.

22. Vallerini D, Barozzi P, Quadrelli C, Bosco R, Potenza L, et al. (2008) Parvoviruses in blood donors and transplant patients, Italy. Emerg Infect Dis 14: 185-186.

23. Lurcharchaiwong W, Chieochansin T, Payungpoon S, Theamboonlers A, Poovorawan Y (2008) Parvovirus 4 (PARV4) in serum of intravenous drug users and blood donors. Infection 36: 488-491.

24. Asiyabi s, Nejati A, Shoja Z, Shahmahmoodi S, Jalilvand S, et al. (2016) First report of human parvovirus 4 detection in Iran. J Med Virol 88: 1314-1318.

25. Touinssi M, Brisbarre N, Picard C, Frassati C, Dussol B, et al. (2010). Parvovirus 4 in blood donors, France. Emerg Infect Dis 16: 165-166. 